Journal of Natural Science and Integration
JNSI: Journal of Natural Science and Integration p-ISSN: 2620-4967 | e-ISSN: 2620-5092 Vol. 3, No. 1, April 2020, Hal 13-25

\title{
Penerapan Flipped Classroom dalam Konteks ESD untuk Meningkatkan Kemampuan Kognitif dan Membangun Sustainability Awareness Siswa
}

\author{
Gabriela Clarisa $^{1}$, Agus Danawan ${ }^{2}$, Muslim$^{3}$, Agus Fani Chandra Wijaya ${ }^{4}$ \\ 1,2,3,4 Program Studi Pendidikan Fisika, Universitas Pendidikan Indonesia \\ e-mail: \\ 1 gabrielaclarisa2@gmail.com \\ 2 ad@upi.edu \\ 3 muslim@upi.edu \\ 4Agus.fany@gmail.com
}

\begin{abstract}
.
Flipped Classroom is a $21^{\text {st }}$ century teaching method that facilitates students to autonomously learn outside the classroom, followed by discussions or active learning in the classroom. Education for Sustainable Development (ESD) refers to contexts or issues that could be discussed in the preferred teaching method in relation to ESD which aims to develop students' Sustainability Awareness. This research was conducted in the form of one group pretest-posttest design, involving 29 students in a State-Owned Secondary School in Bandung. Several instruments were used in this research including a cognitive scale in the form of multiple choice test, Sustainability Awareness questionnaires and observation sheets to collect data related to the Flipped Classroom implementation within the context of ESD. The results of this research indicated that the implementation of Flipped Classroom within the context of ESD successfully improved students' cognitive skill and developed students'Sustainability Awareness.
\end{abstract}

Keywords: flipped classroom, education for sustainable development (esd), cognitive skill, sustainability awareness

\begin{abstract}
ABSTRAK.
Flipped Classroom merupakan model pembelajaran abad 21 yang memfasilitasi siswa mempelajari konten (belajar) di luar kelas atau di rumah secara mandiri, kemudian melakukan diskusi atau active learning di kelas. Education for Sustainable Development (ESD) merupakan suatu konteks atau isu-isu yang akan dijadikan masalah terkait model pembelajaran yang digunakan dan berkaitan dengan ESD yang dapat membangun Sustainability Awareness siswa. Penerapan Flipped Classroom dalam konteks ESD pada penelitian ini bertujuan untuk meningkatkan kemampuan kognitif dan membangun Sustainability Awareness siswa. Penelitian ini menggunakan desain The one group pretest-posttest design. Instrumen yang digunakan adalah tes kemampuan kognitif dalam bentuk soal pilihan ganda, angket Sustainability Awareness, dan lembar observasi keterlaksanaan Flipped Classroom dalam konteks ESD. Instrumen diberikan kepada 29 siswa di salah satu SMP Negeri di Kota Bandung. Hasil penelitian menunjukkan bahwa penerapan Flipped Classroom dalam konteks ESD dapat meningkatkan kemampuan kognitif siswa dan membangun Sustainability Awareness setelah kegiatan pembelajaran.
\end{abstract}

Kata kunci: flipped classroom, education for sustainable development (esd), kemampuan kognitif, sustainability awareness 


\section{PENDAHULUAN}

Kurikulum 2013 pada mata Nasional (2010-2014) tidak secara eksplisit menyatakan komitmen terhadap ESD, tetapi pada dasarnya pendidikan nasional Indonesia didedikasikan pada keseluruhan aspek pembangunan nasional, khususnya pengembangan SDM yang bersesuaian dengan tuntutan pembangunan dalam pelajaran fisika secara implisit sudah mengarah pada konsep pendidikan pembangunan berkelanjutan (PPB) atau education for sustainable development (ESD). Seperti adanya penerapan ilmu pengetahuan di dalam kehidupan sehari-hari yang berkaitan dengan isu-isu lingkungan, dengan adanya pembelajaran semacam itu diharapkan proses pembelajaran yang berlangsung di sekolah bisa menjadi lebih bermakna dan dapat mengarahkan siswa untuk berpikir ke depan serta memiliki kesadaran atas nilai-nilai berkelanjutan (sustainability awareness).

Seorang guru mata pelajaran Fisika dalam Kurikulum 2013 dituntut untuk memilih dan menggunakan metode pembelajaran yang sesuai sehingga dapat meningkatkan nilai-nilai sustainability awareness siswa. Kurikulum 2013, siswa dibimbing untuk mengkonstruksi pengetahuan dibenak mereka sendiri sehingga dengan adanya hal tersebut anak belajar mengalami, mencatat sendiri pengetahuan baru yang didapatkan bukan diberi begitu saja oleh guru dan pengetahuan yang dimiliki seseorang itu mencerminkan pemahaman yang mendalam mengenai suatu persoalan (subject matter). Empat pilar Pendidikan yang dirancang oleh UNESCO yaitu learning to do learning to know, learning to be, and learning to live together. Pembelajaran tidak seharusnya berpusat pada guru saja tetapi siswa adalah pusat belajar sesungguhnya. Siswa harus digali potensi dan kemampuannya (learning to do) dengan meningkatkan mobilitas kegiatan, sehingga siswa akan mempunyai rasa kaingintahuan yang tinggi (learning to know). Kegiatan yang membuat siswa lebih aktif dan sangat mementingkan peran siswa diharapkan akan bisa membuat siswa lebih kreatif (learning to be). Kekreatifan siswa akan memberikan semangat belajar tinggi antar sesame siswa yang akan menjadikan proses pembelajaran lebih menarik dan efisien (learning to live together) (Sukini, 2019)

Pelaksanaan Pembelajaran fisika saat ini masih mengalami banyak kendala. Baik ditinjau dari individual peserta didik maupun guru. Dalam upaya menciptakan proses belajar mengajar yang efektif dan efisien, maka guru perlu memperhatikan prinsip-prinsip mengajar diantaranya dengan menggunakan alat bantu mengajar atau alat peraga. Mata pelajaran IPA- fisika seharusnya merupakan suatu pelajaran yang ditunggu-tunggu, disenangi, menantang dan bermakna bagi peserta didik. Dengan meningkatnya pengguna smartphone dan penggunaan internet setiap tahun, diharapkan kualitas pendidikan pun ikut meningkat (Statista, 2018)

Namun, saat ini berbagai permasalahan sering muncul dalam dunia pendidikan seperti kurang adanya inovasi model pembelajaran yang berdampak pada kurang aktifnya peserta didik ketika belajar di kelas (BAS, 2010; Schaal, 2010) dalam (Aşiksoy, 2016), dengan pendekatan tradisional juga membuat siswa tidak menyadari hubungan antara konsep fisika dengan kehidupan nyata. Berdasarkan fakta yang terjadi di lapangan (sekolah di Indonesia) bahwa pembelajaran yang dilakukan di sekolah dominan menggunakan metode ceramah, sehingga peserta didik hanya mendengarkan, menulis, bertanya dan yang bertanya biasanya hanya beberapa orang saja, jadi siswa cenderung bersifat pasif sedangkan yang bersifat aktif biasanya hanya guru saja sebagai pemberi informasi.

Berdasarkan hasil observasi di kelas VII salah satu SMP Negeri di Bandung kelas VII diperoleh temuan bahwa pembelajaran yang sering dilakukan adalah metode ceramah sesekali melakukan percobaan/demonstrasi. Beberapa siswa mengalami kesulitan saat mengerjakan PR di rumah karena tidak memahami materi yang dijelaskan guru di kelas. Hampir sebagian besar siswa menyimpan buku pegangan di sekolah sehingga ketika di rumah siswa tidak menggulang kembali materi yang didapat di sekolah dan tidak dapat mempelajari materi yang akan dipelajari di sekolah sehingga ketika siswa mengikuti pelajaran di dalam kelas siswa tidak memiliki bekal apapun untuk dipelajari di dalam kelas. Selain itu, siswa lebih senang menggunakan smartphone sebagai media hiburan bukan untuk pembelajaran. Mereka lebih senang menghabiskan waktunya untuk bermain game daripada harus memahami konsep materi pelajaran . 
Penggunaan pembelajaran yang didukung dengan penggunaan teknologi salah satunya yaitu Flipped Classroom. Flipped Classroom ini bertujuan untuk menimbulkan rasa ketertarikan pada diri siswa, karena IPA-Fisika merupakan mata pelajaran yang erat dengan kehidupan sehari-hari. Pembelajaran dengan Flipped Classroom dapat melatih siswa menjadi lebih aktif saat pembelajaran karena dalam mengkonstruksi konsep, siswa akan mempelajari melalui kegiatan diskusi di kelas.

Dengan model flipped classroom dengan pendekatan Education for Sustainaible Development (ESD) di dalam kurikulum 2013 telah menunjukan bahwa pendidikan karakter berlaku di Indonesia. Hal itu ditunjukkan dengan adanya kompetensi inti mengenai sikap religius dan sikap sosial disetiap mata pelajaran. Dalam perspektif pembangunan berkelanjutan pada dasarnya mengajarkan tata nilai, bahwa manusia dapat memahami dirinya dan makhluk lain serta dapat memahami hubungannya dengan lingkungan alam dan sosial yang lebih jelas.

Pada tahun 2002 di Johannesburg, UNESCO resmi mengenalkan konsep Education for Sustainable Development (ESD) di dalam pendidikan sebagai pendekatan dalam pembelajaran yang mendukung pembangunan berkelanjutan. Pendidikan untuk keberlanjutan (ESD) adalah proses belajar sepanjang hayat yang bertujuan untuk menginformasikan dan melibatkan penduduk supaya kreatif juga memiliki keterampilan menyelesaikan masalah, saintifik, dan sosial literasi, lalu berkomitmen untuk terikat pada tanggung jawab pribadi dan kelompok (UNESCO, 2015) Pembelajaran dengan konteks ESD akan mengarahkan siswa untuk belajar mengajukan pertanyaan yang kritis, belajar memperjelas nilai-nilai seseorang, belajar untuk membayangkan masa depan yang lebih positif dan berkelanjutan, belajar berpikir sistematik, dan lainnya (Tilbury, 2011). Diharapkan siswa dapat menyelesaikan permasalahan yang nyata dalam pembelajaran dengan memperhatikan dampak bagi lingkungan, social, dan ekonomi.

Berdasarkan uraian di atas, maka pembelajaran menggunakan konteks ESD dapat mengarahkan siswa untuk memiliki keterampilan dalam menyelesaikan masalah sehingga minat dan prestasi belajar siswa dapat meningkat. Dengan menggunakan konteks ESD kedalam model pembelajaran Flipped Classroom diharapkan dapat meningkatkan kemampuan kognitif siswa dan siswa akan memiliki kesadaran atas nilai-nilai keberlanjutan (sustainability awareness). Sustainability awareness merupakan kesadaran berkelanjutan terkait lingkungan sekitar siswa atau dapat dikatakan juga sebagai kesadararan untuk menjaga serta menghargai lingkungan dan kehidupan disekitarnya. Sebaiknya Sustainability awareness dibangun sejak dini karena Sustainability awareness merupakan komponen yang sangat penting untuk mendukung pembangunan berkelanjutan. Kemudian dengan belajar aktif siswa akan belajar lebih efektif dan konsisten ketika belajar suatu konsep yang dikaitkan dengan kehidupan nyata, di dalam pembelajaran aktif guru hanya sebagai pembimbing dan menyiapkan kondisi kelas untuk pembelajaran, sedangkan siswa berpartisipasi aktif secara kognitif, emosional, sosial dan fisik.

Model pembelajaran yang diterapkan oleh seorang guru dapat mempengaruhi kemampuan kognitif siswa. Oleh karena itu peneliti bermaksud mengadakan penelitian mengenai "Penerapan Flipped Classroom Dalam Konteks ESD Untuk Meningkatkan Kemampuan Kognitif dan membangun Sustainability Awareness siswa"

\section{METODOLOGI}

Penelitian yang akan dilakukan adalah penelitian kuantitatif dengan menggunakan beberapa instrumen penelitian dalam mengukur hasil yang didapatkan. Penelitian kuantitatif banyak dituntut menggunakan angka, mulai dari pengumpulan data, penafsiran terhadap data tersebut, serta penampilan dari hasilnya, serta pemahaman akan kesimpulan penelitian akan lebih baik jika disertai Tabel, grafik, bagan, gambar atau tampilan lain (Arikunto,2014).Metode penelitian yang digunakan adalah metode quasi-experiment. Desain penelitian yang dipakai adalah The one group pretest-posttest design. 
Dengan menggunakan desain ini, peneliti hanya akan meneliti satu kelas sehingga tidak diperlukan kelas pembanding, sebelumnya pada kelas ini diberikan suatu tes awal (pretest) untuk mengetahui kemampuan kognitif siswa secara pasti. Setelah diberikan tes awal, selanjutnya siswa akan diberi treatment yaitu pembelajaran IPA-fisika dengan menggunakan model Flipped Classroom. Setelah treatment selesai diberikan maka siswa akan diberikan tes akhir (posttest) untuk mengetahui dengan pasti sejauh mana pengaruh pembelajaran IPA-fisika dengan menggunakan model Flipped Classroom terhadap peningkatan kemampuan kognitif. Desain penelitian The one group pretest posttest design disajikan pada Tabel 1.

Tabel 1. Desain penelitian the one group pretest-posttest design

\begin{tabular}{rrr}
\hline Pretest & Treatment & Posttest \\
\hline $\mathbf{O}_{1}$ & $\mathrm{X}$ & $\mathbf{O}_{2}$ \\
\hline
\end{tabular}

Populasi dalam penelitian adalah seluruh siswa kelas VII di salah satu SMP negeri di Kota Bandung. Sampel sebanyak 29 siswa yang diambil sebanyak satu kelas yang sesuai dan dapat dijadikan sebagai objek untuk penelitian. Teknik pengambilan sampel yang diambil adalah convenience sampling.

Instrumen yang digunakan dalam penelitian ini adalah Tes Kemampuan Kognitif. Tes yang dilakukan berupa soal pilihan ganda sebanyak 18 soal yang berkaitan dengan materi Energi. Tes ini bertujuan untuk mengetahui peningkatan kemampuan kognitif setelah diterapkannya model Flipped Classroom yang dialami siswa yang merupakan sampel penelitian. Untuk mengukur peningkatan kemampuan kognitif siswa yang diperoleh sebelum dan sesudah pembelajaran. Maka dihitunglah dengan menggunakan nilai rata-rata gain yang dinrmalisasi. Perumusan rata-rata gain yang dinormalisasi menurut Hake (1998, hlm 4) adalah sebagai berikut :

$$
<\mathrm{g}>=\frac{\%<\boldsymbol{G}>}{\%<\boldsymbol{G}>\max }=\frac{(\%<\boldsymbol{S} \boldsymbol{f}>-\%<\boldsymbol{S i}>)}{(100-\%<\boldsymbol{S i}>)}
$$

Keterangan :

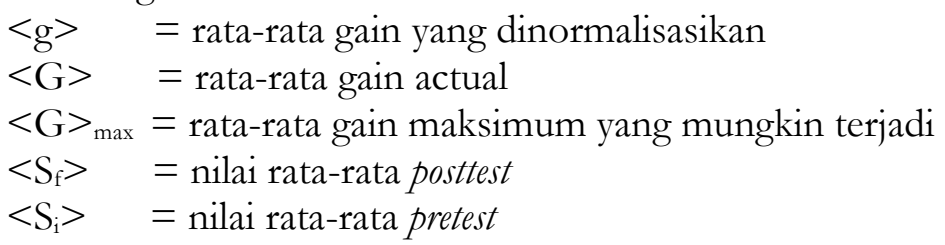

Nilai rata-rata $N$-Gain yang diperoleh kemudian diinterpretasikan kriteria nilai gain disajikan dalam tabel 3.10.

Tabel 2. Interpretasi nilai gain yang dinormalisasi

\begin{tabular}{cl}
\hline Nilai rata-rata N-Gain & Kategori \\
\hline$(<\mathrm{g}>) \geq 0,7$ & Tinggi \\
\hline $0,7>(<\mathrm{g}>) \geq 0,3$ & Sedang \\
\hline$(<\mathrm{g}>)<0,3$ & Rendah \\
\hline
\end{tabular}

Instrumen yang digunakan dalam penelitian ini yaiitu angket sustainability awareness. Sustainability Awareness merupakan salah satu Sustainability Awareness merupakan salah satu penunjang keterlaksanaan konsep ESD yang memiliki arti sikap peduli yang ditunjukkan oleh seseorang terhadap permasalahan lingkungan dengan menghargai dan melestarikan lingkungan serta kehidupan di sekitarnya. Untuk mengetahui Sustainability Awareness siswa pada materi energi maka digunakan instrumen berupa angket dengan jumlah pernyataan 15 yang diadaptasi dari jurnal yang berjudul "The status on the level of environmental awareness in the concept of sustainable development amongst secondary school students". 
Dibawah merupakan angket yang digunakan untuk mengetahui sikap Sustainability Awareness siswa:

Tabel 3.angket sustainability awareness

\begin{tabular}{|c|c|c|}
\hline No & Pernyataan & Tidak \\
\hline 1 & Saya membaca tentang isu lingkungan di media massa & \\
\hline 2 & Saya peduli dengan masalah lingkungan dengan teman-teman saya & \\
\hline 3 & $\begin{array}{l}\text { Saya selalu membahas masalah lingkungan dengan teman-teman } \\
\text { saya }\end{array}$ & \\
\hline 4 & Saya merasa kecewa dengan polusi udara & \\
\hline 5 & Saya merasa kecewa dengan polusi sungai & \\
\hline 6 & Saya menghargai keanekaragaman hayati & \\
\hline 7 & Saya peduli tentang asap yang berasal dari kendaraan-kendaraan & \\
\hline 8 & $\begin{array}{l}\text { Saya mencoba mengurangi jumlah sampah di rumah dengan } \\
\text { menggumpulkan bahan yang bias didaur ulang }\end{array}$ & \\
\hline 9 & Saya mengomposkan sisa makanan menjadi pupuk & \\
\hline 10 & $\begin{array}{l}\text { Saya tidak menggunakan kantong plastik untuk membungkus } \\
\text { barang }\end{array}$ & \\
\hline 11 & Saya menghidupkan lampu dirumah pada siang hari & \\
\hline 12 & Saya menghemat pemakaian air bersih & \\
\hline 13 & $\begin{array}{l}\text { Saya menyampaikan informasi tentang lingkungan kepada anggota } \\
\text { keluarga saya }\end{array}$ & \\
\hline 14 & Saya mengikuti dalam kegiatan penyadaran lingkungan disekolah & \\
\hline 15 & Saya menyadari tanggung jawab saya terhadap lingkungan & \\
\hline
\end{tabular}

Pada akhir pertemuan, siswa diberikan angket Sustainability Awareness. Data yang didapatkan dari hasil angket ini kemudian diolah. Sustainability awareness siswa didapatkan dari hasil pengisian angket checklist yang berjumlah 15 pernyataan, diadopsi dari jurnal diolah menggunakan skala guttman. Skala Guttman merupakan salah satu skala pengukuran yang dapat digunakan dalam soal pilihan ganda, skala Guttman juga dapat digunakan dalam bentuk lembar checklist serta akan mendapatkan jawaban yang tegas seperti "benar-salah", "positif-negatif", "ya-tidak", dan lain-lain dengan data berupa data interval. Pada skala Guttman ini jawaban dapat dibuat skor tertinggi satu dan terendah nol, untuk jawaban ya diberi skor 1 dan jawaban tidak diberi skor 0. Kemudian data dibuat ke dalam bentuk persentase dengan cara sebagai berikut:

$$
\text { Persentase }(\%)=\frac{\text { Jumlah skor yang diperoleh }}{\text { Jumlah skor maksimum }} \times 100 \%
$$

Setelah didapatkan hasilnya dengan menggunakan skala Guttman maka untuk memprofilkan sustainability awareness diklasifikasikan berdasarkan kriteria yang ada pada tabel 4 :

Tabel 4. Persentase sustainability awareness

\begin{tabular}{cc}
\hline $\begin{array}{c}\text { Persentase sustainability } \\
\text { awareness }\end{array}$ & Meaning \\
\hline $0.0 \%-50.0 \%$ & Practices that seldom or dislike to be done \\
\hline $51.0 \%-70.0 \%$ & Practices that are done/ happened moderate/ medium \\
\hline $70.0 \%-100.0 \%$ & Practices/feelings that are most likely one/ happende \\
\hline
\end{tabular}

Lembar observasi keterlaksanaan RPP dilakukan dengan observasi atau biasa disebut dengan istilah pengamatan, merupakan salah satu cara yang dilakukan oleh peneliti untuk memperoleh data dengan penelitian langsung terhadap kondisi lingkungan objek penelitian yang mendukung kegiatan penelitian dengan tujuan untuk mengetahui hasil belajar siswa (Kholia Urwati, 2019) Lembar observasi digunakan untuk mengetahui keterlaksanaan pembelajaran dan respon siswa terhadap model pembelajaran Flipped Classroom yang digunakan yaitu berupa lembar checklist. Di dalam lembar 
checklist tersebut terdiri atas tujuh tahap pembelajaran dengan tujuh tahap pembelajaran. Pada tahap pendahuluan peryataan yang ada pada lembar observasi akan mengukur apersepsi dan motivasi yang dikaitkan dengan tiga aspek dalam ESD yaitu aspek sosial, lingkungan dan ekonomi. Cara mengolah data dalam lembar observasi ini, dengan cara membubuhkan tanda checklist pada kolom penilaian jika kegiatan pembelajaran terlaksana dan dengan pemberian skor ideal (SI) dan skor observasi (SO) 1 jika kegiatan pembelajaran yang sesuai dan 0 jika kegiatan pembelajaran tidak sesuai. Jumlah skor SI dan SO tidak selalu sama melainkan disesuaikan dengan jumlah kegiatan pembelajaran yang ada pada lembar observasi.

Data hasil observasi yang diperoleh dari lembar keterlaksanaan pembelajaran oleh guru dan dua orang praktikan dianalisis dengan tahapan sebagai berikut :

a. Menjumlahkan kegiatan yang terlaksana dengan dengan menerapkan model Flipped Classroom dalam konteks ESD dalam pembelajaran

b. Menghitung persentase keterlaksanaannya dengan menggunakan rumus :

$\%$ Keterlaksanaan Pembelajaran $=\frac{\Sigma \text { skor kegiatan yang terlaksana }}{\Sigma \text { skor total }} \times 100 \%$

Tabel 5. Interpretasi keterlaksanaan model pembelajaran

\begin{tabular}{cl}
\hline $\begin{array}{c}\text { Keterlaksanaan Model } \\
\text { Pembelajaran }(\text { KM) } \%\end{array}$ & Kriteria \\
\hline $0,00 \leq \mathrm{x} \leq 25,00$ & Sangat kurang \\
\hline $25,00<\mathrm{x} \leq 37,60$ & Kurang \\
\hline $37,60<\mathrm{x} \leq 62,60$ & Sedang \\
\hline $62,60<\mathrm{x} \leq 87,60$ & Baik \\
\hline $87,60<\mathrm{x} \leq 100,00$ & Sangat baik \\
\hline
\end{tabular}

\section{TEMUAN DAN PEMBAHASAN}

Untuk mengukur kemampuan kognititif pada materi energi, digunakan instrumen tes pilihan ganda yang terdiri dari 18 butir soal. Bobot untuk setiap butir soal adalah 1 sehingga, nilai ideal yang didapatkan siswa jika semua jawabannya benar adalah 100. Peningkatan kemampuan kognitif diperoleh dari selisih antara nilai posttest dan pretest dengan soal yang sama berdasarkan nilai N-gain yang dinormalisasi berdasarkan kategori Hake. Nilai N-Gain kemampuan kognitif disajikan dalam Tabel 5.

Tabel 6. Tabel rata-rata skor pretest, posttest, N-gain dan kategori nilai N-Gain

\begin{tabular}{cccc}
\hline \multicolumn{3}{c}{ Rata-rata Skor } & Kategori \\
\cline { 1 - 3 } Pretest & Posttest & N-Gain & \\
\hline 71 & 93 & 0.76 & Tinggi
\end{tabular}

Tabel 5 menyajikan data rekapitulasi hasil tes kemampuan kognitif siswa, dapat dilihat bahwa nilai N-gain rata-rata yaitu 0.76. Menurut Hake dapat dikatakan bahwa peningkatan kemampuan kognitif siswa setelah dilaksanakannya model pembelajaran Flipped Classroom dalam konteks ESD memiliki kriteria tinggi. Berdasarkan data yang diperoleh, nilai N-Gain untuk setiap siswa bertanda positif dan tidak ada juga nilai N-Gain yang nilainya nol "0", sehingga dapat dikatakan bahwa tidak ada siswa yang mengalami penurunan kemampuan kognitif dan tidak ada siswa yang tidak mengalami peningkatan kemampuan kognitif setelah mengikuti pembelajaran dengan menggunakan model pembelajaran Flipped Classroom dalam konteks ESD ini.

Untuk mengetahui peningkatan kemampuan kognitif diuji melalui N-gain ternormalisasi. Peningkatan kemampuan kognitif dapat diketahui setelah siswa mengerjakan soal tes kemampuan 
kognitif, baik sebelum dan sesudah diterapkannya model pembelajaran Flipped Classroom dalam konteks Education Sustainable Development (ESD) pada materi Energi. Soal yang dikembangkan berupa pilihan ganda sebanyak 18 soal. Aspek kemampuan kognitif yang diukur dalam penelitian ini yaitu C3 (mengaplikasi), C4 (menganalisis) dan C5 (mengevaluasi) yang terbagi kedalam beberapa indikator soal seperti disajikan pada Tabel 3.3. Untuk memperoleh analisis data yang lebih akurat, peneliti juga melakukan perhitungan nilai rata-rata pretest dan posttest untuk setiap ranah kognitif. Nilai rata-rata pretest dan posttest berdasarkan tingkatan ranah kognitif pada C3 (menerapkan), C4 (menganalisis), dan C5 (mengevaluasi). Hasil analisis nilai $\mathrm{N}$-gain untuk setiap aspek kemampuan kognitif disajikan pada tabel 7.

Tabel 7. Nilai N-Gain untuk setiap aspek kemampuan kognitif

\begin{tabular}{cccc}
\hline $\begin{array}{c}\text { Tingkatan } \\
\text { Kognitif }\end{array}$ & $\begin{array}{c}\text { Mengaplikasi } \\
\text { (C3) }\end{array}$ & $\begin{array}{c}\text { Menganalisis } \\
\text { (C4) }\end{array}$ & $\begin{array}{c}\text { Mengevaluasi } \\
\text { (C5) }\end{array}$ \\
\hline $\begin{array}{c}\text { Rata-rata N- } \\
\text { Gain }\end{array}$ & 0.74 & 0.83 & 0.68 \\
\hline Kategori & Tinggi & Tinggi & Sedang
\end{tabular}

Berdasarkan Tabel 7, dapat dilihat bahwa nilai N-Gain untuk setiap aspek Kemampuan kognitif mengalami peningkatan dengan kriteria sedang sampai tinggi. Berdasarkan Tabel 6, peningkatan pada tingkatan menerapkan dan menganalisis memiliki nilai rata-rata $\mathrm{N}$-gain 0.74 dan 0.83 sehingga peningkatan pada tingkatan C3 dan C4 ini tergolong kategori tingi. Sedangkatan peningkatan pada tingkatan mengevaluasi memiliki nilai rata-rata $\mathrm{N}$-gain 0.68 yang menyatakan untuk tingkatan ranah kognitif C5 ini tergolong pada kategori sedang. Kemampuan mengaplikasikan (C3) dan menganalisis (C4) tersebut dapat dijadikan sebagai dasar agar peserta didik dapat meningkatkan kemampuan mengevaluasi (C5).

Kemampuan kognitif siswa setelah diterapkan Flipped Classroom mengalami Peningkatan. Nilai rata-rata pretest untuk hasil belajar kognitif peserta didik sebesar 71 setelah diberikan perlakuan yaitu penerapan Flipped Classroom pada materi energi selama dua pertemuan, nilai rata-rata posttest peserta didik sebesar 93. Dengan perolehan nilai rata-rata pretest dan posttest ini didapat rata-rata gain yang dinormalisasikan sebesar 0.76 atau 76\%. Menurut Hake (1998) perolehan n-gain tersebut terkategori tinggi, artinya kemampuan kognitif siswa setelah diberikan perlakuan mengalami peningkatan yang baik atau terkategori tinggi. Perbandingan nilai $\mathrm{N}$-gain setiap ranah kognitif untuk kategori menganalisis (C4) memperoleh nilai N-gain 0.83 dengan kategori tinggi dan kategori mengevaluasi (C5) memperoleh nilai $\mathrm{N}$-gain 0.68 dengan kategori sedang.

Dengan diterapkannya Flipped Classroom ini, 52\% penelitian menunjukan bahwa dengan menggunakan model flipped ini dapat meningkatkan prestasi belajar siswa, ketika diukur dengan GPA (IPK)-nya, dari beberapa skor tes standar (standardized test scores), dan tingkatan kelas (course grade) (Nurpianti,2018). Hasil temuan Zaher Atwa (2016) dinilai Flipped Classroom lebih efektif untuk meningkatkan kemampuan kognitif siswa. Wulansari (2018) model Flipped Classroom berpengaruh pada hasil belajar kognitif.

Untuk mengidentifikasi sustainability awareness siswa setelah integrasi Education for Sustainable Development (ESD) dalam model pembelajaran Flipped Classroom, penulis menggunakan angket Sustanability Awareness diadopsi dari karya Hasan dkk (2010). Jumlah pernyataan pada angket Sustainability Awareness sebanyak 15 butir. Pertanyaan pada angket tersebut dibagi menjadi tiga kategori yaitu Sustainability practice awareness, behavioral and attitude awareness dan emotional awareness.

Berdasarkan rekapitulasi angket sustainability awareness, diperoleh persentase siswa memiliki kesadaran akan Pendidikan untuk pembangunan berkelanjutan (ESD Awareness) seebesar 67\% dengan interpretasi Practices that are done/happened moderate/medium. Dapat dikatakan bahwa siswa sudah mempraktikan Pendidikan berkelanjutan namun hal ini terjadi hanya sesekali, dan 
dikategorikan "sedang atau medium". Persentase respon siswa pada setiap kategori disajikan pada tabel 8:

Tabel 8. Persentase respon pada setiap kategori sustainability awareness

\begin{tabular}{ccc}
\hline $\begin{array}{c}\text { Kategori Sustainability Awareness } \\
\text { Sustainability practice } \\
\text { awareness }\end{array}$ & $\begin{array}{c}\text { Persetase } \\
(\%)\end{array}$ & Keterangan \\
\hline $\begin{array}{c}\text { Behavioral and attitude } \\
\text { awareness }\end{array}$ & 44.2 & Jarang dilakukan \\
\hline Emotional awareness & 69.2 & Biasa dilakukan \\
\hline
\end{tabular}

Berdasarkan Tabel 8 Sustainability Awareness diikelompokkan kedalam 3 kategori. Kategori yang pertama yaitu Sustainability practice awareness hasil yang didapatkan menunjukkan bahwa perilaku tersebut jarang dilakukan oleh sebagian besar jumlah siswa dengan persentase $55.8 \%$, sedangkan untuk siswa yang melakukan perilaku tersebut sebesar $44.2 \%$. Dengan adanya hal tersebut, dapat disimpulkan bahwa siswa tidak pernah melakukan perilaku Sustainability practice awareness. Sustainability practice awareness atau upaya sadar dan menjalankan keberlanjutan itu sangat jarang atau bahkan tidak pernah dilakukan oleh siswa seperti membahas isu lingkungan dengan teman, mengomposkan sisa makanan menjadi pupuk, tidak menggunakan kantong plastik untuk membungkus barang, membahas mengenai masalah lingkungan dengan keluarga dan juga mengikuti kegiatan penyadaran lingkungan disekolah untuk mengatasi permasalahan lingkungan itu semua sangat jarang dilakukan oleh siswa berdasarkan angket yang mereka isi. Perilaku tersebut merupakan ciri dari sikap yang akan ditunjukkan apabila seseorang sudah mengerti tentang konsep keberlanjutan.

Kategori yang kedua yaitu Behavioral and attitude awareness atau perilaku dan sikap peduli terhadap lingkungan dari jumlah seluruh siswa dapat dikatakan bahwa $69.2 \%$ siswa melakukan perilaku tersebut dan 30.8\% siswa tidak melakukan perilaku tersebut. Sehingga dapat disimpulkan bahwa perilaku dan sikap peduli terhadap lingkungan (Behavioral and attitude awareness) yang dimiliki siswa sedang. Behavioral and attitude awareness atau perilaku dan sikap peduli terhadap lingkungan tidak dilakukan siswa seperti membaca isu lingkungan di media massa, menghargai keanekaragaman hayati, peduli terhadap asap kendaraan bermotor, mendaur ulang sampah rumah tangga, tidak menyalakan lampu disiang hari dan mengurangi pemakaian air bersih sering dilakukan atau yang paling mungkin terjadi di dalam kehidupan. Hal tersebut merupakan perilaku dan sikap yang ditunjukkan apabila seseorang peduli dan sadar akan pentingnya lingkungan.

Kategori yang ketiga yaitu Emotional awareness atau kepeduliian terhadap lingkungan secara emosi termasuk sikap atau perilaku yang selalu dilakukan oleh seluruh siswa, persentase jumlah siswa yang bersikap Emotional awareness sebesar 92.3\%, secara emosional siswa memiliki kepedulian tinggi terhadap lingkungannya. Kepedulian terhadap lingkungan secara emosional seperti merasa peduli dengan permasalahan lingkungan, merasa kecewa dengan polusi yang ada diudara dan sungai serta sadar akan tanggung jawab manusia terhadap lingkungan itu dimiliki oleh peserta didik. Sehingga Sustainability awareness atau kepedulian berkelanjutan siswa berdasarkan kategorinya yang paling baik hanya peduli terhadap lingkungan secara emosional dan masih jarang kepeduliannya ditunjukkan dengan sikap apalagi secara keberlanjutan . sehingga dapat disimpulkan bahwa berdasarkan 3 kategori Sustainability awareness siswwa hanya memiliki kesadaran terhadap nilai keberlanjutan pada tingkat emosi tanpa mempraktekannya dalam kehidupan sehari-hari ditunjukkan dengan nilai terbesa dengan perilaku tidak pernah melakukannya pada kategori Sustainability practice awareness.

Sustainability awareness dapat mendukung konsep Pendidikan berkelanjutan atau ESD sehingga dengan hasil profil Sustainability awareness dengan kategori sedang dapat dikatakan bahwa sikap siswa yang diteliti sudah cukup untuk mendukung terhadap konsep ESD tersebut. Namun, hal 
tersebut belum sesuai dengan yang dikatakan oleh Hasan (2010) bahwa yang dapat mendukung konsep ESD yaitu Sustainability awareness yang tinggi.

Berdasarkan temuan di lapangan, diperoleh persentase siswa yang memiliki kesadaran akan pendidikan untuk pembangunan berkelanjutan (ESD Awareness) yaitu 67\% dengan interpretasi Practices that are done/ happened moderate/medium Hasan dkk (2010). Temuan ini juga sejalan dengan temuan Hasan dkk (2010) yang menyatakan bahwa ESD Awarenss siswa berada pada tingkat sedang yang berarti siswa hanya sesekali mempraktikan perilaku keberlanjutan. Dari ketiga kategori, kategori yang memperoleh presentasi paling tinggi adalah emotional awareness dengan persentase sebesar $92.3 \%$, hal ini sejalan dengan temuan Hasan dkk (2010) yang menyatakan bahwa secara emosi, siswa sadar akan konsep pembangunan berkelanjutan, siswa percaya bahwa harus ada keseimbangan antara lingkungan dan pembangunan. Sementara itu, sustainability practice awareness siswa adalah yang terendah dengan persentase $44.2 \%$.

Menurut Kelompok kerja LSM untuk PPB Indonesia (2014) menyatakan bahwa penerapan Pendidika untuk pembangunan berkelanjutan (ESD) untuk pendidikan formal, sudah dimulai sejak tahun 2005 dengan peluncuran Program Adiwiyata oleh Kementerian Lingkungan Hidup (KLH), berarti sudah 14 tahun sejak peluncuran program tersebut namun praktik berkelanjutan yang dilaksanakan oleh siswa masih tergolong rendah. Menurut Kelompok kerja LSM untuk PPB Indonesia. (2014) menyatakan bahwa pemerintah pusat sudah memahami dengan baik mengenai konsep pendidikan untuk berkelanjutan ini (ESD), namun wacana ESD ini kurang menjangkau dengan baik hingga ke pemerintah daerah, sehingga dapat dikatakan bahwa salah satu alasan mengapa sustainability practice awareness siswa berada pada tingkat yang rendah karena kurangnya pemahaman mulai dari pemerintah maupun pihak sekolah mengenai konsep pendidikan untuk pembangunan berkelanjutan ini.

Indrati dan Hariyadi (2016) menjelaskan bahwa ESD merupakan sarana untuk mentransfer pengetahuan, nilai-nilai, dan keterampilan serta mengembangkan kapasitas manusia terkait dengan isu-isu keberlanjutan sehingga mereka dapat menentukan cara untuk mempertahankan hidupnya. Hal ini sejalan dengan apa yang dilakukan oleh peneliti dengan memasukkan konteks ESD ke dalam pembelajaran sebagai upaya untuk mengembangkan manusia terkait dengan isu-isu berkelanjutan. Pada pembelajaran, dihadirkan isu keberlanjutan seperti siswa diminta untuk memilih jawaban dengan mempertimbangkan aspek lingkungan, ekonomi, dan juga sosial dimana ketiga aspek tersebut merupakan tiga pilar utama dalam ESD.

Indrati dan Hariyadi (2016) juga mengemukakan bahwa peran guru dalam ESD melalui mata pelajaran diharapkan dapat mengajak siswa untuk lebih mengetahui mengenai apa itu pembangunan berkelanjutan dan bagaimana pembangunan berkelanjutan yang ada di Indonesia. Guru diminta untuk menganalisis kembali kompetensi dasar dan perangkat pembelajaran lainnya yang mungkin bisa disisipi konteks ESD. Hal ini sejalan dengan apa yang dilakukan oleh peneliti, peneliti mencoba membuat perangkat pembelajaran dengan menyisipkan konteks ESD di dalamnya sebagai upaya mengajak siswa memahami apa itu pembangunan berkelanjutan. Suprastowo (2010) berpendapat yang serupa, bahwa Indonesia memiliki kewajiban untuk mengintegrasikan prinsip-prinsip, nilai, dan praktek pembangunan berkelanjutan ke dalam pendidikan dan pembelajaran yang sejalan dengan konsep ESD.

Untuk mengidentifikasi keterlaksanaan pembelajaran, Penelitian ini dilaksanakan dengan menggunakan model pembelajaran Flipped Classroom dalam konteks ESD pada materi pembelajaran IPA-fisika yaitu Energi. Penelitian ini dilaksanakan dalam waktu dua kali pertemuan dengan durasi pertemuan pertama $2 \times 40$ menit dan pertemuan kedua $3 \times 40$ menit. Pada saat pembelajaran peneliti menekankan dan mengenalkan ESD di setiap langkah pembelajaran. Keterlaksanaan model pembelajaran Flipped Classroom dalam konteks ESD ini dinilai oleh dua observer. Setiap observer diberi lembar checklist kegiatan dan dikoordinasikan terlebih dahulu dengan setiap observer agar tidak terjadi kesalah pahaman antara observer dengan peneliti. Pada lembar observasi tersebut terdiri dari langkah- 
langkah pembelajaran, kegiatan guru dan kegiatan siswa serta catatan diakhir lembar observasi. Langkah-langkah pembelajaran pada Flipped Classroom ini terdiri dari tahap pendahuluan (brainstorming), tahap budaya belajar, menyajikan konsep yang konseptual, menganalisis dan mengevaluasi pembelajaran dan penutup. Pada tahap pendahuluan, siswa menafsirkan hasil representasi visual terkait video dan materi yang sudah disampaikan menjadi ungkapan verbal dengan menjelaskan hasil belajarnya di luar kelas dan mengevaluasi hasil pembelajaran dengan diskusi bersama. Proses ini juga melibatkan guru dimana pertanyaan arahan yang dilontarkan mampu menuntun siswa untuk berpikir lebih jauh sehingga terpancing untuk menemukan jawaban sendiri (Irma Suryani, 2019) Pada tahap budaya belajar, siswa dikelompokkan ke dalam beberapa kelompok untuk berdiskusi. Pada tahap ini, siswa bebas mengeksplor sendiri, diskusi dan tukar pikiran dan guru menjadi fasilitator yang membimbing siswa.

Pada tahap selanjutnya adalah menyajikan konsep yang kontekstual. Pada tahap ini guru memberikan stimulan dengan demonstarasi dan berdiskusi dengan siswa. Setelah itu siswa berdiskusi dan mengerjakan soal. Perwakilan kelompok untuk mempresentasian temuan yang didapatkan sedangkan siswa lain mendengarkan dan menanggapi hasil temuan yang diperoleh temannya. Setelah menyajikan konsep, langkah selanjutnya adalah menganalisis dan mengevaluasi hasil pembelajaran. Siswa diminta untuk menyimpulkan bersama apa yang diperoleh dari hasil pembelajaran. Langkah terakhir adalah penutup dengan mengingatkan siswa untuk menonton video di rumah kegiatan preclass dan refleksi diri.

Pertemuan pertama terdiri dari tahap pendahuluan (Brainstorming) ada 8 kegiatan guru dan siswa jika terlaksana seluruhnya. Selanjutnya tahap budaya belajar terdapat 2 kegiatan guru dan siswa. Tahap ketiga ialah menyajikan konsep yang konseptual terdapat 6 kegiatan siswa dan guru. Tahap keempat yaitu menganalisis dan mengevaluasi pembelajaran terdapat 2 kegiatan guru dan siswa juga terakhir penutup yang terdiri dari 2 kegiatan siswa dan guru.

Pertemuan kedua, langkah pendahuluan terdiri dari 8 kegiatan, langkah budaya belajar 3 kegiatan, menyajikan konsep yang konseptual 4 kegiatan, tahap menganalisis dan mengevaluasi pembelajaran 5 kegiatan dan penutup terdiri dari 2 kegiatan.

\section{Tabel 9. Rekapitulasi persentase keterlaksanaan kegiatan guru dalam pembelajaran flipped classroom dalam konteks ESD}

\begin{tabular}{ccc}
\hline \multicolumn{2}{c}{ Keterlaksanaan model } & KM Total \\
\cline { 1 - 2 } Pertemuan 1 & Pertemuan 2 & \\
\hline $95 \%$ & $100 \%$ & $97.5 \%$ \\
\hline
\end{tabular}

Berdasarkan Tabel 9 keterlaksanaan dalam pembelajaran menggunakan Flipped Classroom yang dipadukan dengan konteks ESD oleh guru secara keseluruhan sebesar 97.5\% yang berarti bahwa kegiatan pembelajaran hampir seluruh kegiatan terlaksana. Pertemuan pertama guru menyampaikan terkait konsep energi, bentuk-bentuk energi, sumber energi dan prinsip kerja PLTA dan mengenalkan konsep ESD kepada siswa. Pada pelaksanaan pembelajaran siswa diarahkan peduli terhadap lingkungan. Pada pertemuan kedua guru menyampaikan transformasi energi dan dikaitkan pada sellsurya dan fotosintesis pada tumbuhan. Rekapitulasi Persentase Keterlaksanaan Kegiatan Siswa dalam pembelajaran Flipped Classroom dalam konteks ESD disajikan pada Tabel 10. 


\section{Tabel 10. Rekapitulasi persentase keterlaksanaan kegiatan siswa dalam pembelajaran flipped classroom dalam konteks ESD}

\begin{tabular}{ccc}
\hline \multicolumn{2}{c}{ Keterlaksanaan model } & KM Total \\
\cline { 1 - 2 } Pertemuan 1 & Pertemuan 2 & \\
\hline $90 \%$ & $100 \%$ & $95 \%$ \\
\hline
\end{tabular}

Berdasarkan Tabel 6 keterlaksanaan dalam pembelajaran Flipped Classroom yang dipadukan dengan ESD oleh siswa secara keseluruhan yaitu sebesar 95\% yang artinya sebagian besar kegiatan terlaksana dengan cukup baik. Dari hasil rekapitulasi persentase keterlaksanaan pembelajaran Flipped Classroom dalam konteks ESD, Persentase keterlaksanaan pembelajaran oleh guru dan siswa secara keseluruhan adalah 96.2\% artinya hampir seluruh kegiatan pembelajaran terlaksana.

\section{SIMPULAN}

Berdasarkan pengolahan dan analisis terhadap data hasil penelitian yang telah peneliti dapatkan di lapangan, maka dapat disimpulkan yang dapat menjawab pertanyaan dalam penelitian ini, yaitu terdapat peningkatan kemampuan kognitif dan sustainability awareness siswa. Pada pokok bahasan energi dengan isu ESD setelah diimplementasikan dalam pembelajaran fisika menggunakan model Flipped Classroom dalam konteks ESD menunjukkan peningkatan termasuk kategori sedang. Dengan hasil Sustainability Awareness siswa yang terbagi menjadi 3 kategori yaitu Sustainability practice awareness dengan presentase sebesar $44.2 \%$ sangat jarang dilakukan, Behavioral and attitude awareness presentase 69.2\% biasa dilakukan dan Emotional awareness dengan presentase 99,3\% sering dilakukan oleh siswa. Peningkatan kemampuan kognitif dengan Nilai rata-rata N-Gain 0.76 dengan kategori tinggi. Sehingga dapat disimpulkan bahwa Pembelajaran dengan model Flipped classroom dan dapat membangun sustainability awareness siswa . Berdasarkan 3 kategori Sustainability Awareness siswa hanya memiliki kesadaran terhadap nilai keberlanjutan pada tingkat emosi tanpa mempraktekannya dalam kehidupan sehari-hari ditunjukkan dengan nilai terbesar dengan prilaku tidak pernah melakukannya pada kategori Sustainability practice awareness.

\section{REFERENSI}

Arikunto, S. (2014). Prosedur Penelitian Suatu Pendekatan Praktis. Jakarta: Rineka Cipta.

Arikunto, S. (2015). Dasar-Dasar Evaluasi Pendidikan. Jakarta: Bumi Aksara.

Assiksoy, G. (2017). The effects of the gamified flipped classroom environment on students' motivation, learning achievements and perception in a physics course. Springer Science, DOI 10.1007/s11135-017-0597-1.

Atwa, Z., Din, R. \& Hussin, M. (2016). Effectiveness of flipped learning in physics education on Palestinian high school student's achievement. Journal of Personalized Learning, 2(1):73-85

Bell, M. R. (2015). An Investigation of the impact of Flipped Classroom Instructional Approach on High School Students' Content Knowledge and Attitudes toward the learning Environment. Retrieved from All Thesis and Dissertation: https//scholarsarchive.byu.edu/etd/4444

Burmeister, M., Rauch, F., \& Eilks, I. (2012). Education for Sustainable Development (ESD) and chemistry education. Chem.Educ.Res.Pract.,2012,13,59-68.

Hake, R.R. (1998). Interactive-engagement vs traditional methods: A six- thousand student survey of mechanics test data for introductory physics course, American Journal of Physics, $66,64-$ 74

Hake, R.R. (1998). Analyzing Change/Gain score. Dept. of physics, Indiana University.

Hasan, A. Ariffin, T. Sulaiman, S, The status on the level of environmental awareness in the concept of sustainable development amongst secondary school students", Procedia Social and Behavioral Sciences 2 (2010) 1276 1280, 2010. 
Hutagalung, Inge. (2007). Pengembangan kepribadian Tinjauan Praktis Menuju Pribadi Positif. Jakarta :Indeks

Indrati, D. A., \& Hariadi, P. P. ESD (EDUCATION FOR SUSTAINABLE DEVELOPMENT) MELALUI PEMBELAJARAN BIOLOGI.

Irma Suryani, R. M. (2019). Penerapan Model Pembelajaran Heuristic Vee Terhadap Peningkatan Pemahaman Konsep Siswa Pada Materi Fluida Statis. Journal of Natural Science and Integration, 173-180.

Kelompok kerja LSM untuk PPB Indonesia. (2014). Perjalanan Education for Sustainable Development di Indonesia dalam Perspektif LSM (Menyongsong akhir Decade of ESD (2005 - 2014)). Jakarta.

Kementrian Pendidikan Nasional. Model Pendidikan untuk Pembangunan Berkelanjutan (Education for Sustainable Development/ ESD) melalui Kegiatan Intrakulikuler", Pusat Penelitian Kebijakan, Balitbang Kemdiknas, Jakarta, 2010.

Kemendikbud. (2003). Undang - Undang Republik Indonesia Nomor 20 tabun 2003 tentang Sistem Pendidikan Nasional. Jakarta: Kemendikbud.

Kemendikbud. (2013). Peraturan Menteri Pendidikan dan Kebudayaan Republik Indonesia Nomor 81 A tahun 2013 tentang Implementasi Kurikulum. Jakarta: Kemendikbud.

K.F. Hew, W. \&. (2018). Applying "First Principles of Instruction" as a design theory of the flipped classroom: Findings from a collective study of four secondary school subjects. Computers \& Education, doi 10.1016/j.compedu.2017.12.003.

K.Hew, K. C. (2017). A critical review of flipped classroom challenges in K-12 education Possible solutions and recommendations for future research. Research and Practice in Technology Enhanced Learning, 12(1).

Kholia Urwati, N. E. (2019). Pengaruk Model Pembelajaran Kooperatif Tipe Jigsaw Terhadap Hasil Belajar Kognitif Siswa Pada Materi Hukum Newton Kelas X MA Darul Muharijin Praya. Journal of Natural Science and Integration, 203-215.

Korsum, I.(2017). The Formation of Learners Motivation to Study Physics in Terms of Sustainable Development of Education in Ukraine. Journal of Teacher Education for Sustainability, vol. 19, no. 1, pp. 117-128.

Latifah,Iif., Nugraha, M.G., Wijaya, Agus F.C. (2018). Integrasi ESD (Education Sustainable Development) dalam Pembelajaran Problem Based Learning (PBL) Untuk Meningkatkan Penguasaan Konsep Siswa SMP .Prosiding Seminar Nasional Fisika (SINAFI). Bandung.

Listiawati.nur.(2011).Relevansi Nilai-Nilai ESD dan Kesiapan Guru Dalam Mengimplementasikannya di Sekolah. Jurrnal Pendidikan dan Kebudayaan. Vol 17/Nomor 2,Maret 2011.h.139-140

Listiawati, N. (2013). Pelaksanaan Pendidikan untuk Pembangunan Berkelanjutan oleh Beberapa Lembaga. Jurnal Pendidikan dan Kebudayaan, 19(3), 430-450

Nurpianti, S., Suwarna,I.R., Jauhari, A. (2018). Kajian Implementasi Pendekatan Flipped Classroom pada Pembelajaran Fisika. ProsidingSeminar NasionalFisika(SINAFI).Bandung.

Nursadiah, Suyana,I.,Ramalis,T.R (2018). Profil Sustainability Awareness Siswa Melalui Integrasi ESD Dalam Pembelajaran Berbasis Masalab Pada Topik Energi di SMP. Prosiding Seminar Nasional Fisika (SINAFI). Bandung

Maolidah, Irna Septiani T. R. (2017). Efektivitas Penerapan Model Pembelajaran Kelas terbalik Pada Peningkatan Kemampuan Berfikir Kritis Siswa. EDUTECHNOLOGIA, Tahun 3, Vol 3 No 2.

Özdamh, G. A. (2016). Flipped Classroom adapted to the ARCS Model of Motivation and applied to a Physics Course. Eurasia Journal of Mathematics, Science \& Technologi Education, 12(6) 15891603.

Statista. (2018). Retrieved from Facebook: Number of monthly active users worldwide 2008-2018": www.statista.com 
Sukini. (2019). Penerapan Pembelajaran Guided Inquiry Berbasis Pendekatan saintifik untuk Meningkatkan Aktivitas dan Hasil Belajar Kognitif Biologi Siswa kelas XI MIPA SMA Negeri 3 Dumai. Journal of Natural Science and Integration, 105-121.

Suprastowo, P. (2010). Kebijakan dan implementasi pendidikan untuk pembangunan berkelanjutan (Education for sustainable development/ESD). jurnal penelitian kebijakan pendidikan.

UNESCO. (2009). Review of Contexts and Structures for Education for Sustainable Development [Online]. Avaible: http://www.unesco.org/education/justpublished desd2009.pdf. [Accessed 18 March 2019].

Tilbury, D. (2011). Education for Sustainable development: An expert review of processes and learning.Paris,France:UNESCO.Diunduhdari:https://www.researchgate.net/publication/ 255963640_Tilbury_D_2011_'Education_for_Sustainable_Development_An_Expert_Re view_of_Processes_and_Learning'Paris_UNESCO_Available_in_Spanish_French_and_ EnglishED-2010WS46. 